Elżbieta Ura (D) https://orcid.org/0000-0001-6896-6790

Uniwersytet Rzeszowski

\title{
ZATRUDNIENIE FUNKCJONARIUSZY W ADMINISTRACJI CELNO-SKARBOWEJ PO REFORMIE
}

\author{
Abstract \\ Employment of officers in customs and tax administration after the reform
}

The article presents the legal regulations concerning the officers of the former Customs Service adopted by the legislator on the occasion of the reformed customs and tax administration and the establishment of the National Tax Administration. The institution of terminating the service relations of officers by law was introduced, as well as transforming the service relations into contractual relations as a result of offering the officer further work in the structures of this administration and accepting this proposal by him. Problems with interpreting these solutions were visible in the varied jurisprudence of administrative courts as well as common courts. In order to understand these difficulties, some of the justifications of the judgments have been presented more broadly. In line with these considerations, the thesis is justified that in recent years the legislator has increasingly resorted to this type of solutions and introduced institutions of termination of employment relations by law, and their cause is not "exceptional, special circumstances justified by the state system reform," which was emphasized by the Constitutional Tribunal, only reforms related to organizational transformations in public administration. This is viewed as the means of replacing public administration staff.

Słowa kluczowe: reforma, administracja celno-skarbowa, stosunki służbowe funkcjonariuszy

Keywords: reform, customs and tax administration, official relations of officers

ASJC: 3308, JEL: K31

\section{Wprowadzenie}

Z dniem 1 marca 2017 roku została wprowadzona - ustawą z dnia 16 listopada 2016 roku o Krajowej Administracji Skarbowej (Dz.U. 2021, poz. 422 tekst jedn. ze zm., dalej: „ustawa o KAS”) oraz ustawą z dnia 16 listopada 2016 roku - Przepisy wprowadzające ustawę o Krajowej Administracji Skarbowej (Dz.U. 2016, poz. 1948, dalej: „ustawa wprowadzająca") - reforma administracji celno-skarbowej. Powodem zmian, zdaniem 
twórców reformy, były: zbyt duża dekoncentracja rzeczowa i terenowa administracji podatkowej, celnej i kontroli skarbowej oraz związana z tym niewydolność działania. Jak wynika z uzasadnienia do projektu ustawy o KAS, administracja podatkowa, celna i skarbowa de facto nie działały według jednolitych procedur, co negatywnie wpływało na stopień ściągalności należnych zobowiązań podatkowych i ukształtowanie budżetu państwa, a co za tym idzie - na możliwości wykonywania funkcji państwowych przez jednostki administracji rządowej, jak również na poziom dobrowolności w wypełnianiu zobowiązań o charakterze powszechnym (uzasadnienie poselskiego projektu ustawy o Krajowej Administracji Skarbowej (2016), druk sejmowy nr 826, Sejm VIII kadencji). Wprowadzone struktury administracji, jak wynika z dalszej części tego 121-stronicowego uzasadnienia, należało dostosować do zmieniających się realiów rynkowych i współpracy $\mathrm{z}$ administracjami państw członkowskich Unii Europejskiej. Funkcjonowanie administracji w niezmienionym od wielu lat kształcie nie odpowiadało realiom gospodarczym i oczekiwaniom państwa oraz klientów administracji.

Głównymi celami reformy, jak wskazuje uzasadnienie, były:

- ograniczenie skali oszustw podatkowych,

- zwiększenie skuteczności poboru należności podatkowych i celnych,

- zwiększenie poziomu dobrowolności wypełniania obowiązków podatkowych,

- zapewnienie wysokiego poziomu obsługi klienta,

- obniżenie kosztów funkcjonowania administracji skarbowej w relacji do poziomu uzyskiwanych dochodów budżetowych,

- rozwój profesjonalnej kadry.

\section{Administracja celno-skarbowa po reformie}

Do czasu wprowadzenia reformy administracja celno-skarbowa funkcjonowała w strukturze terenowej jako administracja niezespolona, skupiona w trzech niezależnie funkcjonujących pionach: administracji podatkowej (16 izb skarbowych oraz 400 urzędów skarbowych), Służby Celnej (16 izb celnych, 45 urzędów celnych wraz ze 141 oddziałami celnymi), kontroli skarbowej (16 urzędów kontroli skarbowej). Organami tej administracji byli dyrektorzy izb skarbowych, dyrektorzy izb celnych, dyrektorzy urzędów kontroli skarbowej oraz naczelnicy urzędów skarbowych i naczelnicy urzędów celnych.

Na mocy ustawy wprowadzającej reformę powołana została Krajowa Administracja Skarbowa (dalej: „KAS”) w miejsce wcześniej funkcjonujących: administracji podatkowej, kontroli skarbowej i Służby Celnej. Powołano, jak określono, administrację skonsolidowaną podporządkowaną ministrowi właściwemu do spraw finansów publicznych. W następstwie tego funkcjonują następujące organy Krajowej Administracji Skarbowej: minister właściwy do spraw finansów publicznych, Szef Krajowej Administracji Skarbowej, dyrektor Krajowej Informacji Skarbowej, dyrektor izby administracji skarbowej, naczelnik urzędu skarbowego, naczelnik urzędu celno-skarbowego. 
Zgodnie z przyjętymi rozwiązaniami, podstawowe zadania w procesie poboru danin realizuje naczelnik urzędu skarbowego, którego zakres kompetencji, w porównaniu do wcześniej funkcjonującego, uległ zmianie. Przejął on kompetencje dotychczasowego naczelnika urzędu skarbowego i naczelnika urzędu celnego w zakresie między innymi poboru podatków, należności celnych, opłat oraz niepodatkowych należności budżetowych, administracyjnej egzekucji należności pieniężnych. Z kolei nowo utworzony organ - naczelnik urzędu celno-skarbowego - realizuje zadania związane między innymi z wykonywaniem kontroli celno-skarbowej, ustalaniem i określaniem podatków, opłat i niepodatkowych należności budżetowych oraz innych czynności przewidzianych przepisami prawa celnego.

Nadzór nad realizacją zadań wykonywanych przez naczelników urzędów skarbowych i urzędów celno-skarbowych powierzony został dyrektorowi izby administracji skarbowej. Terenowe organy administracji celno-skarbowej pozostały, jak wcześniej, w strukturze administracji rządowej niezespolonej w województwie.

Szefa KAS powołuje Prezes Rady Ministrów na wniosek ministra właściwego do spraw finansów publicznych. Jest on równocześnie sekretarzem stanu w Ministerstwie Finansów. Dyrektora Krajowej Informacji Skarbowej i dyrektora izby administracji skarbowej powołuje minister właściwy do spraw finansów publicznych na wniosek Szefa KAS. Dyrektor izby jest organem wyższego stopnia w stosunku do naczelnika urzędu skarbowego i naczelnika urzędu celno-skarbowego.

Naczelnika urzędu skarbowego i naczelnika urzędu celno-skarbowego powołuje Szef KAS na wniosek dyrektora izby administracji skarbowej. Naczelnik urzędu skarbowego może powierzyć prowadzenie w jego imieniu niektórych spraw należących do jego właściwości jednostce samorządu terytorialnego lub związkowi takich jednostek pod warunkiem, że odrębne przepisy tak stanowią (Nowak 2020, s. 37 i n.).

Na podstawie art. 159 ustawy wprowadzającej utraciły moc ustawy stanowiące w poprzednim okresie podstawy prawne funkcjonowania administracji celnej i skarbowej, to jest: ustawa z dnia 28 września 1991 roku o kontroli skarbowej (Dz.U. 2016, poz. 720 tekst jedn. ze zm.), ustawa z dnia 21 czerwca 1996 roku o urzędzie Ministra Finansów oraz o urzędach i izbach skarbowych (Dz.U. 2015, poz. 578 tekst jedn. ze zm.), ustawa z dnia 27 sierpnia 2009 roku o Służbie Celnej (Dz.U. 2016, poz. 1799 tekst jedn. ze zm., dalej: „,ustawa o Służbie Celnej”), ustawa z dnia 10 lipca 2015 roku o administracji podatkowej (Dz.U.2015, poz. 1269 ze zm.).

\section{Rozwiązania prawne dotyczące pracowników i funkcjonariuszy wcześniejszych struktur administracji celno-skarbowej}

Reforma administracji celnej i skarbowej - zniesienie dotychczasowych organów centralnych i terenowych tej administracji - przyniosła ze sobą nie tylko powoływanie nowych organów i zmianę ich właściwości rzeczowej, ale przede wszystkim określone skutki dla pracowników i funkcjonariuszy Służby Celnej zatrudnionych w dotychczasowych 
strukturach administracji skarbowej i celnej, inaczej mówiąc - skutki personalne objawiające się nie tylko zmianą warunków zatrudnienia czy służby, ale również wygaśnięciem stosunków zatrudnienia. Zgodnie z art. 170 ustawy wprowadzającej:

1. Stosunki pracy osób zatrudnionych w jednostkach KAS, o których mowa w art. 36 ust. 1 pkt 2, 3 i 6 ustawy, o której mowa w art. 1, oraz stosunki służbowe osób pełniących służbę w jednostkach KAS, o których mowa w art. 36 ust. 1 pkt 1,2, 3 i 6 ustawy, o której mowa w art. 1, wygasają:

1) z dniem 31 sierpnia 2017 roku, jeżeli osoby te w terminie do dnia 31 maja 2017 roku nie otrzymają pisemnej propozycji określającej nowe warunki zatrudnienia albo pełnienia służby;

2) po upływie 3 miesięcy, licząc od miesiąca następującego po miesiącu, w którym pracownik albo funkcjonariusz złożył oświadczenie o odmowie przyjęcia propozycji zatrudnienia albo pełnienia służby, jednak nie później niż dnia 31 sierpnia 2017 roku.

2. Pracownik albo funkcjonariusz, któremu przedstawiono propozycję zatrudnienia albo pełnienia służby, składa w terminie 14 dni od dnia jej otrzymania oświadczenie o przyjęciu albo odmowie przyjęcia propozycji. Niezłożenie oświadczenia w tym terminie jest równoznaczne z odmową przyjęcia propozycji zatrudnienia albo pełnienia służby.

3.W przypadku, o którym mowa w ust. 1, wygaśnięcie stosunku służbowego funkcjonariusza traktuje się jak zwolnienie ze służby.

4. W przypadku, o którym mowa w ust. 1, pracownikom oraz funkcjonariuszom przysługują świadczenia należne odpowiednio w związku z likwidacją urzędu albo zniesieniem jednostki organizacyjnej w rozumieniu ustawy uchylanej w art. 159 pkt 3.

5. Przepisów ust. 1 i 4 nie stosuje się do urzędników służby cywilnej, do których mają zastosowanie przepisy rozdziału 5 ustawy z dnia 21 listopada 2008 roku o służbie cywilnej (Dz.U. 2016, poz. 1345, 1605 i 1807).

6. Przepisy ust. 1-5 stosuje się odpowiednio do pracowników, o których mowa w art. 167 ust. 1.

7. Pracownicy, o których mowa w art. 167, oraz funkcjonariusze pełniący służbę w urzędzie obsługującym ministra właściwego do spraw finansów publicznych, którym nie zostanie złożona propozycja określająca nowe warunki zatrudnienia albo pełnienia służby w terminie do dnia 31 maja 2017 roku, otrzymują pisemną informację o braku propozycji ${ }^{1}$.

1 Artykuł 36 ust. 1 pkt 1 ustawy o KAS dotyczy komórek organizacyjnych urzędu obsługującego ministra do spraw finansów publicznych, pkt 2 - Krajowej Informacji Skarbowej, pkt 3 - izb administracji skarbowej, pkt 6 - Krajowej Szkoły Skarbowości; art. 159 pkt 3 ustawy wprowadzającej uchyla ustawę o Służbie Celnej; art. 167 ust. 1 ustawy wprowadzającej dotyczy pracowników zatrudnionych w urzędzie obsługującym ministra właściwego do spraw finansów publicznych i wykonujących zadania w komórkach organizacyjnych urzędu obsługującego ministra właściwego do spraw finansów publicznych oraz ministra właściwego do spraw instytucji finansowych, którzy stają się pracownikami zatrudnionymi w urzędzie obsługującym ministra właściwego do spraw finansów publicznych, wykonują zadania KAS i zachowują ciągłość pracy - z zastrzeżeniem art. 170. 
Tak sformułowany artykuł miał szczególny wymiar. Należało go odczytywać łącznie $\mathrm{z}$ art. 165, zgodnie z którym pracownicy zatrudnieni w izbach skarbowych stali się pracownikami zatrudnionymi w izbach administracji skarbowej i zachowali ciągłość pracy (ust. 1), a pracownicy zatrudnieni w izbach celnych oraz urzędach kontroli skarbowej oraz funkcjonariusze celni pełniący służbę w izbach celnych albo w komórkach urzędu obsługującego ministra właściwego do spraw finansów publicznych stali się z dniem wejścia w życie ustawy o KAS odpowiednio pracownikami zatrudnionymi w jednostkach organizacyjnych KAS albo funkcjonariuszami Służby Celno-Skarbowej, wszyscy zachowując ciągłość pracy (ust. 2). Oba przepisy powyższego artykułu wyraźnie jednak dodawały: „Z zastrzeżeniem art. 170”.

Artykuł 166 ustawy wprowadzającej przewidywał podobne rozwiązania w odniesieniu do pracowników wywiadu skarbowego i pracowników wyodrębnionych komórek organizacyjnych kontroli skarbowej.

Należy też wskazać na przepis art. 165 ust. 7 ustawy wprowadzającej stanowiący:

Dyrektor Krajowej Informacji Skarbowej, dyrektor izby administracji skarbowej oraz dyrektor Krajowej Szkoły Skarbowości składają odpowiednio pracownikom oraz funkcjonariuszom, w terminie do dnia 31 maja 2017 roku, pisemną propozycję określającą nowe warunki zatrudnienia albo pełnienia służby, która uwzględnia posiadane kwalifikacje i przebieg dotychczasowej pracy lub służby, a także dotychczasowe miejsce zamieszkania.

Na tej podstawie dyrektorzy izb administracji skarbowej przedstawiali w maju 2017 roku niektórym funkcjonariuszom (dawnej Służby Celnej) propozycje dalszego zatrudnienia, ale nie jako kontynuacji stosunku służbowego, lecz na podstawie umowy o pracę na czas nieokreślony w służbie cywilnej (następowało w ten sposób „ucywilnianie” funkcjonariuszy). Zaproponowane warunki zaczęły obowiązywać osoby, które je przyjęły, od 1 czerwca 2017 roku. Przekształcenie stosunków służbowych w stosunki zatrudnienia na podstawie umowy o pracę na czas nieokreślony było swoistym novum w przyjętych rozwiązaniach prawnych (art. 96 uchylonej ustawy o Służbie Celnej takiego przypadku nie przewidywał).

\section{Skutki prawne przyjętej reformy dla statusu prawnego byłych funkcjonariuszy Służby Celnej}

Przyjęte rozwiązania prawne oznaczały, że z dniem wejścia w życie ustawy o KAS dotychczasowi pracownicy i funkcjonariusze wskazanych jednostek organizacyjnych, którzy stali się z mocy prawa pracownikami i funkcjonariuszami nowej KAS, po krótkim okresie zatrudnienia w nowych strukturach podzieleni zostali na trzy grupy:

- W pierwszej grupie znaleźli się ci funkcjonariusze i pracownicy, którym kierownicy nowo utworzonych jednostek organizacyjnych KAS wymienionych w art. 170, 165 i 167 ustawy wprowadzającej przedstawili do dnia 31 maja 2017 roku pisemną 
propozycję określającą nowe warunki zatrudnienia albo pełnienia służby i którzy przedstawione warunki przyjęli.

- Drugą grupę tworzyli ci, którzy otrzymali propozycję nowych warunków zatrudnienia lub pełnienia służby, ale złożyli oświadczenie o jej odmowie. W takim przypadku ich stosunki zatrudnienia lub stosunki służbowe wygasły po upływie 3 miesięcy, licząc od miesiąca następującego po miesiącu, w którym takie oświadczenie złożyli. Termin na złożenie oświadczenia wynosił 14 dni od otrzymania propozycji, a niezłożenie w tym terminie oświadczenia było równoznaczne z odmową przyjęcia propozycji zatrudnienia lub pełnienia służby.

- W trzeciej grupie znaleźli się pracownicy i funkcjonariusze, którzy nie otrzymali propozycji dalszego zatrudnienia, co oznaczało, że ich stosunki zatrudnienia wygasły z mocy prawa, bez jakiejkolwiek czynności którejś ze stron tego stosunku, z dniem 31 sierpnia 2017 roku. Jest to więc unormowanie szczególne, będące odstępstwem od ogólnych przepisów wymagających oświadczenia woli (decyzji przy stosunku służbowym) co do rozwiązania stosunków zatrudnienia lub służbowych w ustawowo określonych przypadkach. Wygaśnięcie stosunku służbowego w odniesieniu do funkcjonariuszy celnych traktowane było jak zwolnienie ze służby.

Status prawny funkcjonariuszy byłej Służby Celnej kształtowała zatem jedna z trzech sytuacji:

- kontynuowanie stosunku służbowego w związku z przyjęciem propozycji pełnienia służby funkcjonariusza Służby Celno-Skarbowej,

- przekształcenie stosunku służbowego w umowny stosunek pracy w korpusie służby cywilnej na podstawie przyjętej propozycji zatrudnienia umownego,

- wygaśnięcie stosunku służbowego w związku z brakiem propozycji kontynuowania stosunku zatrudnienia w ogóle lub z powodu odmowy przyjęcia nowych warunków zatrudnienia ${ }^{2}$.

Należy przy tym zwrócić uwagę, że ukształtowanie na nowych zasadach dalszego zatrudnienia - bądź jako funkcjonariusza, bądź jako tak zwanego pracownika

2 W wyroku z dnia 23 kwietnia 2020 roku Wojewódzki Sąd Administracyjny w Warszawie orzekł: „W sytuacji, gdy funkcjonariuszowi nie zaproponowano pełnienia dalszej służby ani nie przedstawiono propozycji zatrudnienia, przyjąć trzeba, że istnieje obowiązek organu do wydania decyzji deklaratoryjnej, która stwierdzałaby zwolnienie funkcjonariusza ze służby. Podobnie rzecz się ma z funkcjonariuszem, który odmówił przyjęcia propozycji zatrudnienia albo służby" (II SA/Wa 2652/19, LEX nr 3072213). Wydając decyzję stwierdzającą zwolnienie funkcjonariusza ze służby na skutek wygaśnięcia stosunku służbowego wobec nieprzedstawienia mu propozycji służby, organ każdorazowo jest zobowiązany wziąć pod uwagę i rozważyć kryteria, o jakich mowa w art. 165 ust. 7 ustawy wprowadzającej (wyrok Naczelnego Sądu Administracyjnego z dnia 11 marca 2020 roku, I OSK 2767/19, LEX nr 3009676; wyrok Naczelnego Sądu Administracyjnego z dnia 15 stycznia 2021 roku, III OSK 1407/21, LEX nr 3117611; wyrok Sądu Najwyższego z dnia 22 stycznia 2020 roku, I PK 209/18, LEX 2772555). 
cywilnego - zależało od oświadczania danej osoby - przyjęcia propozycji dalszego zatrudnienia w nowych strukturach Krajowej Administracji Skarbowej. Oczywiście kontynuowanie służby przez funkcjonariuszy było rozwiązaniem najkorzystniejszym, gdyż stosunek służbowy (administracyjnoprawny) funkcjonariusza trwał nadal przy określeniu decyzją administracyjną nowych warunków i miejsca. Zgodne jest też stanowisko sądów administracyjnych, że wygaśnięcie stosunku służbowego wymagało wydania decyzji, co pozwalało na kontrolę sądową zasadności wygaśnięcia stosunku służbowego. Natomiast zupełnie odmienna sytuacja dotyczy funkcjonariuszy „ucywilnionych”, co zostanie przedstawione $\mathrm{w}$ dalszej części.

\section{Wygaśnięcie stosunków pracy pracowników administracji państwowej w okresie tworzenia samorządu terytorialnego}

Pierwszy raz instytucję wygaśnięcia stosunków pracy na skutek braku złożenia propozycji dalszego zatrudnienia lub odmowy przyjęcia nowej propozycji wprowadzono w związku z utworzeniem samorządu terytorialnego na stopniu gminy w 1990 roku. Uchwalona wówczas ustawa z dnia 22 marca 1990 roku o pracownikach samorządowych (Dz.U. 1990, nr 21, poz. 124) przewidywała nabycie przez pracowników administracji państwowej stopnia podstawowego statusu pracownika samorządowego ex lege, przy zachowaniu uprawnień wynikających z przepisów szczególnych, do dnia nawiązania nowych stosunków pracy na dalszy okres albo do ich wygaśnięcia (Ura 1995, s. 108-109). Na tle tak przyjętych rozwiązań Sąd Najwyższy w wyroku z dnia 16 czerwca 2009 roku (I PK 24/09, LEX nr 515695) wyjaśnił:

Kontynuowanie zatrudnienia wymaga nawiązania nowego stosunku pracy, a więc ten poprzedni ulega
przekształceniu w drodze swoistego i wymuszonego na pracowniku „porozumienia stron”, w którym
pracodawca zobowiązuje się zatrudniać pracownika na określonych warunkach, niekoniecznie
dotychczasowych, a pracownik warunki te przyjmuje, wiedząc, że w przeciwnym razie stosunek
pracy wygaśnie z dniem 31 grudnia 1990 roku. Pracownik [w rozpatrywanym stanie faktycznym
chodziło o pracownika mianowanego - przyp. E.U.] nie staje zatem przed alternatywą kontynuacji
dotychczasowego zatrudnienia w niezmienionej postaci a wygaśnięciem stosunku pracy, ale przed
ustawowo zastrzeżonym wyborem między kontynuowaniem zatrudnienia na nowych warunkach
a wygaśnięciem stosunku pracy. Koncepcja przeciwna, z której wynikałby obowiązek zatrudniania
pracownika na dotychczasowych warunkach, włącznie z tą samą podstawą nawiązania stosunku
pracy, nie znajduje zatem uzasadnienia w wykładni językowej.

Podobna sytuacja miała miejsce w wyniku dalszego etapu zmian ustrojowych dokonanych w latach 1998 i 1999, gdy utworzono samorządy powiatowe oraz samorządy wojewódzkie. Ustawa z dnia 13 października 1998 roku - Przepisy wprowadzające ustawy reformujące administrację publiczną (Dz.U. 1988, nr 133, poz. 872, dalej: , ustawa z dnia 13 października 1998 roku") określiła, że pracownicy urzędów wojewódzkich, wykonujący do dnia wejścia 
w życie ustawy zadania i kompetencje podlegające przejęciu przez samorząd województwa lub powiatu, z dniem 1 stycznia 1999 roku stali się odpowiednio pracownikami urzędu marszałkowskiego lub starostwa powiatowego. Jednocześnie ustawa określiła, że stosunki zatrudnienia pracowników likwidowanych urzędów rejonowych i innych, których zadania przejął samorząd województwa lub powiatu, wygasały z dniem 30 czerwca, jeżeli przed dniem 31 maja 1999 roku nie zostały im zaproponowane nowe warunki pracy lub płacy na dalszy okres albo w razie ich nieprzyjęcia do dnia 15 czerwca 1999 roku (art. 58). W obu podanych przykładach - jak w przypadku reformowanej administracji celno-skarbowej - występowały następujące analogiczne sytuacje:

- wygaśnięcie stosunku pracy z mocy prawa, gdy nie zostały zaproponowane nowe warunki pracy lub płacy na dalszy okres albo gdy pracownik nie przyjął nowych warunków pracy lub płacy,

- pracownicy administracji samorządowej mogli przyjąć proponowane im nowe warunki pracy lub płacy,

- przewidziano możliwość rozwiązania stosunku pracy za wypowiedzeniem przed upływem wyżej wskazanych terminów i przy odpowiednim stosowaniu art. 411 Kodeksu pracy (ustawa z dnia 26 czerwca 1974 roku - Kodeks pracy, Dz.U. 2020, poz. 1320 tekst jedn. ze zm., dalej: „Kodeks pracy”, „k.p.”).

Różnica - i to podstawowa - dotyczyła tego, że rozwiązania te nie odnosiły się do funkcjonariuszy i przekształcenia stosunku służbowego w stosunek pracy.

\section{Rozwiązania przyjęte w ustawie z dnia 13 października 1998 roku w ocenie Trybunału Konstytucyjnego}

Rozwiązania przyjęte w ustawie z dnia 13 października 1998 roku oceniał Trybunał Konstytucyjny i w wyroku z dnia 13 marca 2000 roku (K 1/99, OTK 2000, nr 2, poz. 59) uznał przepis art. 58 ust. 3 za niekonstytucyjny w zakresie, w jakim nakazywał odpowiednie stosowanie art. $41^{1}$ k.p., natomiast nie dopatrzył się takiej niezgodności co do przepisu art. 58 ust. 1 określającego skutek niezaproponowania nowych warunków zatrudnienia lub odmowy ich przyjęcia, to jest wygaśnięcie stosunku pracy ${ }^{3}$. W uzasadnieniu rozstrzygnięcia co do przepisu zawartego w art. 58 ust. 1 - ten jest interesujący z punktu widzenia rozważań dotyczących administracji celno-skarbowej - Trybunał Konstytucyjny uznał, że zasada przyjęta w tym przepisie stanowi rozwiązanie nadzwyczajne, ale uzasadnione i możliwe do zastosowania tylko w wyjątkowych sytuacjach,

3 Również Trybunał Konstytucyjny w wyroku z dnia 12 lipca 2011 roku (K 26/09, OTK-A 2011, nr 6, poz. 54) uznał, że wygaszanie stosunków pracy z mocy prawa może być zastosowane tylko w sytuacjach nadzwyczajnych, a w wyroku z dnia 24 października 2017 roku (K 1/17, OTK-A 2017, poz. 79) podniósł, że ingerencja $\mathrm{w}$ stosunki pracownicze powinna dokonywać się z poszanowaniem bezpieczeństwa prawnego osób, których takie regulacje dotyczą, oraz z poszanowaniem gwarancji, które wykluczają arbitralność decydentów i nadmierną dolegliwość ograniczeń. 
ze względu na specyficzne okoliczności, które towarzyszą działaniom reformacyjnym prowadzonym na tak dużą skalę, mimo dolegliwości, które powstają w związku z jego wprowadzeniem dla adresatów tegoż przepisu. Jednocześnie Trybunał Konstytucyjny zastrzegł, że rozwiązanie takie nie może stać się zasadą powszechnie stosowaną i nie można go bez konstytucyjnie uprawnionego uzasadnienia przyjmować w innych sytuacjach, gdyż - biorąc pod uwagę nadzwyczajność i wyjątkowość takiej zasady - ustawodawca nie powinien jej stosować, gdy nie usprawiedliwia tego potrzeba zabezpieczenia innych niż ochrona pracy konkurencyjnych wartości konstytucyjnych.

Trybunał Konstytucyjny podkreślił też, że na gruncie tak określonego stanu prawnego nie występuje jakiekolwiek oświadczenie woli czy też decyzja pracodawcy powodująca skutek w postaci wypowiedzenia bądź rozwiązania umowy o pracę. Umowa wygasa bowiem z mocy samego prawa po spełnieniu się przesłanki w postaci upływu określonego terminu. Również nieprzyjęcie przez pracownika zaproponowanych mu nowych warunków pracy lub płacy na dalszy okres nie stanowi elementu władczego działania ze strony pracodawcy, któremu można byłoby przyznać cechy wypowiedzenia (decyzji o wypowiedzeniu) skutkującej rozwiązaniem stosunku pracy. Odrzucenie zaproponowanych warunków pracy stanowi - na gruncie takich rozwiązań - jedynie przesłankę wygaśnięcia stosunku pracy z mocy prawa na zasadach ogólnych przewidzianych w tejże ustawie. Pracownik w gruncie rzeczy decyduje wtedy sam o tym, czy poddać się ogólnej zasadzie wygaśnięcia stosunków pracy z mocy prawa, czy też przyjąć nowe warunki pracy. Jeżeli nie przyjmie nowych warunków pracy, to niejako godzi się na wygaśnięcie dotychczasowego stosunku pracy z mocy samego prawa.

Trybunał Konstytucyjny odniósł się też do kwestii ochrony praw nabytych, stwierdzając w powołanym uzasadnieniu, że ochrona ta nie może iść tak daleko, aby uniemożliwiała zasadniczą reformę polskiego systemu prawnego, w tym systemu norm regulujących funkcjonowanie organów administracji publicznej. Nie dopatrzył się też naruszenia zasady ochrony pewności prawa. Uznał, że reforma ustroju państwa, w tym ustroju administracji publicznej, dotyczy samych fundamentów ładu publicznego w państwie. W takim przypadku istnieją wystarczająco silne argumenty przemawiające za odstąpieniem od zasady stabilności i pewności prawa. Zmiana warunków społecznych lub gospodarczych może wymagać zmian regulacji prawnych, w tym również zmian, które dotyczą nawiązywania i rozwiązywania stosunków pracy. W końcu Trybunał Konstytucyjny stwierdził, że wprowadzone przepisy nie naruszały również art. 78 Konstytucji Rzeczypospolitej Polskiej z dnia 2 kwietnia 1997 roku (Dz.U. 1997, nr 78, poz. 483 z dnia 16 lipca 1997 roku, dalej: „Konstytucja RP”), gdyż instytucja wygaśnięcia stosunku pracy z mocy prawa została wprowadzona ustawowo, co powoduje, że nie ma ani podstawy prawnej, ani nawet możliwości władczego oświadczenia woli przez pracodawcę, jak również wydania decyzji lub orzeczenia przez właściwe organy państwa, których skutkiem byłoby ustanie stosunku pracy. Pracodawca, nie mając innej możliwości, jedynie powiadamia pracownika, iż w ustawowo określonym terminie stosunek pracy wygasł. Nie ma on żadnych możliwości korzystania z określonego prawem władztwa, ponieważ zakres takiego władztwa nie został przewidziany. Nie ma więc możliwości 
ani negatywnego, ani pozytywnego odniesienia się do sytuacji prawnych powstałych z mocy samego prawa. Trybunał wywodził, że określona w art. 78 Konstytucji RP zasada znajduje zastosowanie tylko w sytuacji, w której prawa i wolności podlegają konkretyzacji i indywidualizacji, a więc wtedy, gdy istnieje możliwość wydawania indywidualnych rozstrzygnięć prawnych (decyzji, orzeczeń itd.). Nie można zatem mówić o prawie do zaskarżenia orzeczeń i decyzji wydanych w pierwszej instancji, gdy nie istnieją - i nie mogą istnieć ze względu na naturę powstałych stosunków prawnych - indywidualne rozstrzygnięcia. Poza Trybunałem Konstytucyjnym żaden sąd czy organ administracji nie ma kompetencji orzekania o obowiązywaniu lub nieobowiązywaniu konkretnych przepisów prawa, zwłaszcza przepisów ustawowych, ponieważ nie jest sądem nad prawem

W tym miejscu trzeba też wskazać, że podobne rozwiązanie, to jest wygaśnięcie stosunku zatrudnienia $\mathrm{z}$ mocy ustawy, wprowadzono również $\mathrm{w}$ art. 51 ust. 7 ustawy z dnia 10 lutego 2017 roku - Przepisy wprowadzające ustawę o Krajowym Ośrodku Wsparcia Rolnictwa (Dz.U. 2017, poz. 624) (Świątkowski 2018, s. 9; Płażek 2019, s. 24; wyrok Sądu Najwyższego z dnia 12 sierpnia 2020 roku, II PK 4/19, LEX nr 3071522) w związku z reformą agencji działających na rzecz rolnictwa (ustawa z dnia 10 lutego 2017 roku o Krajowym Ośrodku Wsparcia Rolnictwa, Dz.U. 2020, poz. 481 tekst jedn.) ${ }^{5}$.

\section{Wygaśniecie stosunków służbowych funkcjonariuszy w wyniku reformy celno-skarbowej}

Przenosząc przedstawioną argumentację Trybunału Konstytucyjnego na grunt rozwiązań zawartych w ustawie wprowadzającej reformę administracji celno-skarbowej, można powiedzieć, że przyjęte rozwiązania nie naruszają postanowień konstytucji w zakresie rozpatrywanym w podobnych okolicznościach. Równocześnie można jednak postawić pytanie: czy reformy ustrojowe z lat 1998-1999 - a wcześniej związane $\mathrm{z}$ utworzeniem samorządu terytorialnego na stopniu gminy - można porównać do reformy administracji celnej i skarbowej, a co za tym idzie, uznać je za nadzwyczajne, wyjątkowe sytuacje związane z koniecznością realizowania innych ważnych wartości konstytucyjnych? Oczywiście, że nie. Ówczesna reforma związana była z ustrojem państwa, utworzeniem jednostek samorządu terytorialnego, a co za tym idzie, z koniecznością likwidacji organów administracji państwowej oraz zmianami

4 Podobne stanowisko na tle interpretacji art. 58 ust. 1 ustawy z dnia 13 października 1998 roku zawarł Sąd Najwyższy w wyroku z dnia 24 maja 2001 roku, I PKN 399/00 (OSNP 2003, nr 6, poz. 143).

${ }^{5}$ Jak wynika z oceny reformy administracji rolnej dokonanej przez NIK, w ustawie wprowadzającej tę reformę nie zabezpieczono interesów pracowników likwidowanych agencji, a przyjęte rozwiązania dawały podstawę do arbitralnych decyzji odnośnie do propozycji dalszego zatrudnienia i nowych warunków pracy (NIK 2020). Nadużywanie ustawowego wygaszania stosunków zatrudnienia negatywnie ocenił również Rzecznik Praw Obywatelskich (Biuletyn Informacji Publicznej RPO 2020). Kwestię tę poruszył również Sąd Najwyższy w wyroku z dnia 26 września 2019 roku (III PK 126/18, OSNP 2020, nr 8, poz. 79). 
w zakresie kompetencji terenowych organów administracji. Wprowadzana zaś reforma administracji celno-skarbowej de facto nie zlikwidowała izb skarbowych czy izb kontroli skarbowej, tylko je przekształciła. Również nie zlikwidowała Służby Celnej, a jedynie w wyniku jej przekształcenia utworzona została Służba Celno-Skarbowa. Czy w tej sytuacji funkcjonariusze dotychczasowych struktur tej administracji nie mogli się stać funkcjonariuszami nowej przekształconej służby (nie tylko na okres przejściowy, jak przyjęto w ustawie)? Wreszcie należy zauważyć, że w przepisach reformujących administrację celno-skarbową nie zostały określone kryteria ustawowe, które pozwoliłyby na ocenę działań podjętych przez dyrektorów izb administracji skarbowej w stosunku do funkcjonariuszy ówczesnej Służby Celnej. Część funkcjonariuszy, którzy nie otrzymali propozycji nowych warunków zatrudnienia lub służby, skorzystało z uprawnień emerytalnych, ale - co trzeba podkreślić - nie wszyscy takie uprawnienia nabyli.

\section{Przekształcenie stosunku służbowego funkcjonariuszy Służby Celnej w stosunek pracy (tak zwane „ucywilnienie” funkcjonariuszy)}

Analizując przyjęte rozwiązania, należy zwrócić uwagę na problem, który stał się (i jest nadal) przedmiotem analiz sądowych oraz różnych stanowisk orzeczniczych. Dotyczy to funkcjonariuszy ówczesnej Służby Celnej, którzy przyjęli propozycję dalszego zatrudnienia na podstawie umowy o pracę i w ten sposób nastąpiło ich „ucywilnienie”. Mimo przyjęcia propozycji dalszego zatrudnienia (z różnych powodów: obawa przed utratą pracy, względy ekonomiczne) osoby te (byli funkcjonariusze) odwoływały się od tak ukształtowanego ich nowego statusu prawnego równolegle do sądów administracyjnych, zarzucając bezczynność dyrektora izby administracji skarbowej - niewydanie decyzji o wygaśnięciu stosunku służbowego, a w końcu również do sądów pracy, wnosząc o ustalenie, że stosunek służbowy trwa nieprzerwanie od 1 marca 2017 roku, ewentualnie o przywrócenie do służby w roli funkcjonariusza Służby Celno-Skarbowej na warunkach sprzed 31 maja 2017 roku. Jako podstawę prawną roszczeń powoływali przepis art. 165 ust. 7 ustawy wprowadzającej, prezentując jego literalną interpretację. Dla przypomnienia treść tego przepisu brzmi: „,... składają odpowiednio pracownikom oraz funkcjonariuszom, w terminie do dnia 31 maja 2017 roku, pisemną propozycję określającą nowe warunki zatrudnienia albo pełnienia służby". W uzasadnieniu odwołań podawano, że użyty przez ustawodawcę zwrot „odpowiednio” oznacza wyraźne wskazanie, że dotychczasowi pracownicy otrzymają propozycję pracy, a funkcjonariusze celni - propozycję służby. Ponadto zarzuty dotyczyły braku podania kryteriów, którymi kierował się dyrektor izby administracji skarbowej, nie przedstawiając funkcjonariuszowi propozycji służby. Odwołujący zwracali też uwagę, że ustawodawca posługuje się dysjunkcją (używając spójnika „albo”), co powinno być interpretowane jedynie w ten sposób, że pracownicy zatrudnieni w izbach celnych oraz urzędach kontroli skarbowej mogli stać się wyłącznie pracownikami zatrudnionymi w jednostkach organizacyjnych KAS, a funkcjonariusze celni pełniący służbę w izbach celnych albo w komórkach 
urzędu obsługującego ministra właściwego do spraw finansów publicznych - wyłącznie funkcjonariuszami Służby Celno-Skarbowej pełniącymi służbę w jednostkach KAS. Według odwołujących inna interpretacja, stosowana w praktyce przez „ucywilnienie” części funkcjonariuszy, jest niezgoda z konstytucją, gdyż narusza zasadę równości i prowadzi do dyskryminacji tych funkcjonariuszy, którym nie zaproponowano służby, a jedynie zatrudnienie, tym bardziej, że zgodnie z obowiązującymi wcześniej unormowaniami Służba Celna była jednolitą umundurowaną formacją. Według odwołujących się „ucywilnienie” części funkcjonariuszy narusza dodatkowo zasadę sprawiedliwości społecznej i zasadę państwa prawnego wyrażoną w art. 2 Konstytucji RP.W odwołaniach podnoszono i to, że funkcjonariusze, którzy przez złożoną propozycję zatrudnienia na podstawie umowy o pracę stali się pracownikami, nie otrzymali decyzji administracyjnej zwalniającej ich ze służby, co uniemożliwiło im złożenie odwołania do Szefa KAS - stąd odwołania wnosili bezpośrednio do sądu administracyjnego. Dodatkowym argumentem wskazywanym w odwołaniach było to, że przedstawienie propozycji „,ucywilnienia” pod groźbą utraty zatrudnienia, w sytuacji gdy do funkcjonariusza nie ma żadnych zastrzeżeń, było sprzeczne z zasadą praworządności, zaufania do organów państwa i z zasadą ochrony stosunku służbowego funkcjonariuszy służby publicznej. Jako uzasadnienie podawano wskazywany wcześniej przepis art. 98 ustawy o Służbie Celnej, który gwarantował, że nieprzyjęcie propozycji zatrudnienia w służbie cywilnej nie skutkowało zwolnieniem ze służby (wyrok Trybunału Konstytucyjnego z dnia 23 września 1997 roku, K 25/96, OTK ZU 1997, nr 3-4, poz. 36; wyrok Trybunału Konstytucyjnego z dnia 14 grudnia 1999 roku, SK 14/98, OTK ZU 1999, nr 7, poz. 163; wyrok Trybunału Konstytucyjnego z dnia 27 stycznia 2003 roku, SK 27/02, OTK ZU 2003, nr 1A, poz. 2; wyrok Trybunału Konstytucyjnego z dnia 19 października 2004 roku, K 1/04, OTK-A 2004, nr 9, poz. 93; wyrok Trybunału Konstytucyjnego z dnia 13 lutego 2007 roku, K 46/05, OTK-A 2007, nr 2, poz. 10; wyrok Wojewódzkiego Sądu Administracyjnego w Warszawie z dnia 24 października 2013 roku, II SA/Wa 1188/13, LEX nr 1637335; wyrok Wojewódzkiego Sądu Administracyjnego w Bydgoszczy z dnia 28 października 2015 roku, II SA/Bd 878/15, LEX nr 1948741; wyrok Naczelnego Sądu Administracyjnego z dnia 7 marca 2017 roku, I OSK 316/2016, CBOSA).

W konkluzji skarżący twierdzili, że wobec braku stosownych decyzji administracyjnych o zwolnieniu ze służby dotychczasowy stosunek służbowy na podstawie aktu mianowania powinien trwać nadal, pomimo przedstawienia propozycji pracy.

Rozbieżności w orzecznictwie wojewódzkich sądów administracyjnych były dość istotne. Niektóre z nich uznawały, że wobec braku ustawowego obowiązku wydania decyzji administracyjnej przez dyrektorów nie są właściwe do rozpoznania skarg (postanowienie Wojewódzkiego Sądu Administracyjnego w Poznaniu z dnia 4 października 2017 roku, II SAB/Po 145/17, LEX nr 2423141; postanowienie Wojewódzkiego Sądu Administracyjnego w Warszawie z dnia 25 października 2017 roku, II SAB/Wa 511/17, LEX nr 2469409; postanowienie Wojewódzkiego Sądu Administracyjnego we Wrocławiu z dnia 23 listopada 2017 roku, IV SA/Wr 665/17, LEX nr 2424198). Później niektóre z sądów administracyjnych zaczęly uznawać, iż istnieje w takich sprawach droga sądowa 
(wyrok Wojewódzkiego Sądu Administracyjnego w Kielcach z dnia 21 listopada 2017 roku, II SAB/Ke 63/17, LEX nr 2422880). Wojewódzki Sąd Administracyjny w Szczecinie w wyroku z dnia 4 października 2017 roku (II SA/Sz 897/17, LEX nr 2377612) uznał, że pisemna propozycja złożona funkcjonariuszowi, określająca nowe warunki zatrudnienia w izbie administracji skarbowej, jest decyzją w rozumieniu art. $104 \$ 1$ ustawy z dnia 14 czerwca 1960 roku - Kodeks postępowania administracyjnego (Dz.U. 2021, poz. 735 tekst jedn.), która podlega zaskarżeniu. Argumentacja wyroku sprowadzała się do stwierdzeń, że:

- Norma art. 169 ust. 4 ustawy wprowadzającej narusza konstytucyjne zasady równości, słusznych oczekiwań, wreszcie prawo do sądu, przez zaniechanie ustawodawcy wprowadzenia mechanizmu ochrony prawnej dla tych osób, które nie otrzymają propozycji pełnienia służby, otrzymają zaś propozycję zatrudnienia w KAS na podstawie umowy o pracę.

- Skoro ustawodawca objął ochroną tych funkcjonariuszy, którym w miejsce służby celnej zaproponowano służbę w Służbie Celno-Skarbowej, to za rażąco niesprawiedliwy należy uznać brak objęcia taką ochroną tych funkcjonariuszy, którym dotychczasowy stosunek mianowania i służby zastępuje się formą dla nich mniej korzystną - stosunkiem pracy. W ocenie sądu funkcjonariusz, który status ten traci, ma prawo do rzetelnego uzasadnienia, zawartego w decyzji administracyjnej, w jaki sposób posiadane przez niego kwalifikacje i przebieg dotychczasowej służby uzasadniają taką, a nie inną zmianę, tym bardziej, że decyzja w zakresie nowych warunków zatrudnienia w istocie ma znacznie szersze pole oddziaływania, wobec czego funkcjonariusz powinien mieć prawo do poznania argumentów, jakie doprowadziły organ do przekonania, że tym funkcjonariuszem już być nie powinien. Rozstrzygnięcie o przeniesieniu funkcjonariusza celnego do pracy na podstawie umowy o pracę nie tylko pozbawia takiego funkcjonariusza dotychczasowej ochrony, ale także potencjalnie: eliminuje go z katalogu osób objętych uprawnieniami emerytalnymi, które przysługują funkcjonariuszom, może spowodować obniżenie wynagrodzenia (brak gwarancji dotychczasowego uposażenia), pozbawia funkcjonariusza dotychczasowych dodatków z tytułu posiadanego stopnia służbowego czy uprawnienia do dodatkowego urlopu wypoczynkowego, przerywa jego ścieżkę kariery zawodowej w Służbie Celnej i powoduje konieczność niezwłocznego przystosowania się do nowych warunków nawet w sytuacji, gdy kilkanaście lat spędził on w danej formacji, deprecjonuje akt mianowania, nie mówiąc już o poczuciu frustracji i niesprawiedliwości.

- Pozbawienie funkcjonariusza, który otrzymuje propozycję zatrudnienia w KAS na podstawie umowy o pracę, ochrony w postaci możliwości złożenia wniosku o ponowne rozpatrzenie sprawy oznacza de facto poddanie funkcjonariuszy celnych procesowi ,ucywilnienia” bez zapewnienia im środków odwoławczych.

- Wprowadzone w art. 169 ust. 4 regulacje pomijające ochronę prawną funkcjonariuszy przenoszonych ze służby do pracy (w konsekwencji ochronę 
prawną ich stosunku służbowego) powinny pozostawać w racjonalnym związku z przyczynami, które rodzą skutek prawny w postaci zmiany stosunku służby na stosunek zatrudnienia (i w tym zakresie legalność tych decyzji podlega kontroli sądowej). To jednak nie usprawiedliwia różnicowania ochrony ich stosunku służbowego w sposób niekorzystny dla tych funkcjonariuszy, którym pełnienia dalszej służby nie zaproponowano.

- Przyjęta przez ustawodawcę norma z art. 169 ust. 4 w zakresie, w jakim pomija pisemną propozycję zatrudnienia, narusza zasadę równości. Brak ratio legis wprowadzonego rozwiązania odmiennego potraktowania funkcjonariuszy, którym złożono pisemną propozycję pełnienia służby, i funkcjonariuszy, którym złożono pisemną propozycję zatrudnienia, implikuje wniosek o naruszeniu przedstawionej zasady.

- Wobec stwierdzenia niekonstytucyjności normy zawartej w art. 169 ust. 4 w zakresie, w jakim pomija pisemną propozycję określającą nowe warunki zatrudnienia, pisemna propozycja nowych warunków zatrudnienia złożona funkcjonariuszowi stanowi decyzję administracyjną.

Inne stanowisko i argumentację zaprezentował Wojewódzki Sąd Administracyjny w Olsztynie w wyroku z dnia 19 października 2017 roku (II SA/Ol 672/17, LEX nr 2381494; podobnie: wyrok Wojewódzkiego Sądu Administracyjnego w Krakowie z dnia 14 listopada 2017 roku, III SA/Kr 890/17, LEX nr 2402045). Sąd ten uznał, że złożenie funkcjonariuszowi pisemnej propozycji, określającej warunki zatrudnienia w ramach korpusu służby cywilnej w Izbie Administracji Skarbowej, poprzedziła czynność organu z zakresu administracji publicznej dotycząca uprawnień funkcjonariusza wynikających z przepisów prawa, która to czynność na mocy art. $3 \$ 2$ pkt 4 ustawy z dnia 30 sierpnia 2002 roku - Prawo o postępowaniu przed sądami administracyjnymi (Dz.U. 2019, poz. 2325 tekst jedn., dalej: „p.p.s.a.") podlega kontroli sądów administracyjnych. Sąd stwierdził, że złożenie funkcjonariuszowi przez organ pisemnej propozycji określającej warunki zatrudnienia (a więc wydanie aktu) było jedynie skutkiem podjętej uprzednio przez organ czynności, która w sposób władczy i jednostronny kształtowała jego sytuację prawną. Pomimo wyposażenia właściwych organów w kompetencje do władczego rozstrzygania o sytuacji prawnej funkcjonariuszy ustawodawca nie wskazał formy prawnej działania organu w tym obszarze, zaś analiza przepisów ustawy wprowadzającej nie pozwala na przyjęcie domniemania formy decyzji administracyjnej.

W dalszych wywodach sąd stwierdził, że powziął wątpliwość co do legalności prawa, na którego podstawie organ podjął zaskarżoną czynność. Podkreślił, że wykładnia gramatyczna art. 165 ust. 7 ustawy wprowadzającej nie jest wystarczająca do prawidłowego odkodowania znaczenia norm prawnych zawartych w tym przepisie. Złożenie tej propozycji było jedynie skutkiem podjętej uprzednio przez organ czynności, która w sposób władczy i jednostronny kształtowała sytuację prawną skarżącego. W art. 165 ust. 7 określone zostały kryteria: „posiadane kwalifikacje i przebieg dotychczasowej pracy lub służby, a także dotychczasowe miejsce zamieszkania”. Przez pryzmat tych kryteriów 
możliwe jest dokonanie obiektywnej oceny przydatności konkretnej osoby (zarówno pracownika, jak i funkcjonariusza) do realizacji zadań w KAS. W przepisie tym nie zawarto natomiast żadnych konkretnych kryteriów, którymi organ winien kierować się w stadium drugim omawianej czynności, w którym organ rozstrzygnął o nawiązaniu z funkcjonariuszem stosunku pracy, a nie stosunku służby. W tym zakresie wystąpiło pominięcie ustawodawcze, co implikowało konieczność rozważenia przez sąd administracyjny, czy nie zachodzi potrzeba bezpośredniego zastosowania Konstytucji RP w celu wypełnienia takiej luki treścią normatywną. Dlatego sąd za konieczne uznał wypełnienie luki prawnej w art. 165 ust. 7 ustawy w drodze bezpośredniego zastosowania przepisów Konstytucji RP, gdyż tylko w taki sposób możliwe było wydanie wyroku chroniącego wartości konstytucyjne i prawidłowo realizującego prawo jednostki do sprawiedliwego wyroku. Podstawowym przepisem konstytucyjnym, który znajduje zastosowanie w sprawie, jest - według sądu - art. 60 Konstytucji RP, w świetle którego „obywatele polscy korzystający z pełni praw publicznych mają prawo dostępu do służby publicznej na jednakowych zasadach". Sąd przywołał tu orzecznictwo Trybunału Konstytucyjnego, w którym przyjęto, że przepis ten obejmuje nie tylko etap naboru do służby publicznej, lecz również zasady wykonywania tej służby, a także zasady zwalniania ze służby publicznej (wyrok Trybunału Konstytucyjnego dnia 23 stycznia 2014 roku, K 51/12, OTK 2014, nr 1, poz. 4). Dalej sąd wywodzi:

\begin{abstract}
Nie powinno budzić wątpliwości, że art. 60 Konstytucji RP znajduje zastosowanie również w przypadku przekształcenia stosunku prawnego łączącego daną osobę z państwem, czy organem państwa - w szczególności przekształcenia stosunku służbowego, którego podstawą jest decyzja administracyjna, w stosunek pracy, którego podstawą jest umowa o pracę. Skoro w kontrolowanej sprawie organ nie wykazał żadnych obiektywnych przesłanek uzasadniających złożenie skarżącemu propozycji zatrudnienia, a nie propozycji służby, należało opowiedzieć się za trwałością stosunku służby skarżącego i obok stwierdzenia bezskuteczności zaskarżonej czynności, na podstawie art. $146 \$ 2$ p.p.s.a., uznać uprawnienie skarżącego do złożenia mu propozycji służby.
\end{abstract}

Widoczne były też różnice w orzecznictwie Naczelnego Sądu Administracyjnego (wyrok Naczelnego Sądu Administracyjnego z dnia 10 kwietnia 2018 roku, I OSK 2768/17, LEX nr 2590998; postanowienie Naczelnego Sądu Administracyjnego z dnia 17 maja 2018 roku, I OSK 1556/18, LEX nr 2593456). Dopiero w wyroku z dnia 5 listopada 2018 roku Naczelny Sąd Administracyjny (I OSK 1044/18, LEX nr 2629079) zobowiązał dyrektora izby administracji skarbowej do wydania decyzji w przedmiocie stosunku służbowego, co jednak nie przesądziło o jednolitości orzecznictwa i nadal inne składy sędziowskie odrzucały skargi kasacyjne funkcjonariuszy (postanowienie Naczelnego Sądu Administracyjnego z dnia 22 sierpnia 2019 roku, I OSK 705/18, LEX nr 2713904). Ostateczne stanowisko wyraził Naczelny Sąd Administracyjny w uchwale składu siedmiu sędziów z dnia 1 lipca 2019 roku (I OPS 1/19, ONSAi WSA 2019, nr 5, poz. 71), stwierdzając, że przyjęcie przez funkcjonariusza propozycji zatrudnienia i przekształcenie, $\mathrm{z}$ dniem określonym w tej propozycji, na podstawie art. 171 ust. 1 pkt 2 ustawy wprowadzającej 
dotychczasowego stosunku służby w służbie przygotowawczej lub stałej w stosunek pracy na podstawie umowy o pracę odpowiednio na czas nieokreślony albo określony nie wiąże się z obowiązkiem właściwego organu do wydania decyzji orzekającej o zakończeniu stosunku służbowego. W uzasadnieniu tej uchwały wskazuje, że:

Zgodnie z art. 165 ust. 7 w zw. z art. 170 ust. 2 ustawy wprowadzającej pisemna propozycja określająca nowe warunki zatrudnienia nie stanowi ani decyzji administracyjnej, o której mowa $\mathrm{w}$ art. $3 \$ 2$ pkt 1 p.p.s.a., ani też innego niż decyzja czy postanowienie aktu lub czynności z zakresu administracji publicznej dotyczącej uprawnienia lub obowiązku wynikającego z przepisu prawa, o których mowa w art. $3 \$ 2$ pkt 4 p.p.s.a. Jest ona natomiast ofertą zawarcia stosunku pracy na podstawie umowy o pracę. Jednakże, aby ten skutek nastąpił, konieczne jest przyjęcie przez funkcjonariusza złożonej mu oferty. Umowa taka zostaje zawarta tylko w sytuacji, gdy funkcjonariusz przyjmie propozycję. Nie ulega zatem wątpliwości, że przekształcenie stosunku służbowego w stosunek pracy dochodzi do skutku za zgodną wolą obu stron.

W związku z tym, zdaniem Naczelnego Sądu Administracyjnego, pisemna propozycja zatrudnienia, nie będąc decyzją administracyjną ani innym aktem lub czynnością, o którym mowa w art. $3 \$ 2$ pkt 4 p.p.s.a., nie jest objęta kognicją sądu administracyjnego. Podkreślił też, że do przekształcenia dochodzi na mocy zgodnego oświadczenia woli organu i dotychczasowego funkcjonariusza i nie jest potrzebne wcześniejsze wygaszenie dotychczasowego stosunku służby w służbie przygotowawczej albo stałej, aby mogło dojść do przekształcenia. Przeciwnie, następstwem tego przekształcenia jest faktyczne zakończenie dotychczasowego stosunku służbowego. Naczelny Sąd Administracyjny uznał też, że przepis o takim charakterze - to znaczy wymagający zgody dotychczasowego funkcjonariusza na przekształcenie - jest konieczny, gdyż przekształcenie stosunku pracy $\mathrm{z}$ mianowania $\mathrm{w}$ stosunek pracy na podstawie umowy o pracę powoduje pogorszenie sytuacji prawnej pracownika. Stosunki pracy z mianowania charakteryzują się zdecydowanie większym stopniem stabilizacji, wynikającym między innymi ze zwiększonej ochrony przed ich rozwiązaniem. Stosunek pracy na podstawie umowy o pracę może być natomiast rozwiązany w każdym momencie, a pracownik z reguły nie ma tych samych uprawnień co funkcjonariusz (na przykład związanych z prawem do lokalu mieszkalnego).

W uzasadnieniu uchwały Naczelny Sąd Administracyjny stwierdził też, że:

Przyjęte przez ustawodawcę rozwiązanie przekształcenia dotychczasowego stosunku służby w służbie przygotowawczej albo stałej w stosunek pracy nie zamyka dotychczasowemu funkcjonariuszowi Służby Celnej prawa dochodzenia swych wolności lub praw na drodze sądowej (art. 77 ust. 2 Konstytucji RP). Przy tym, ustawa p.w. KAS pozostawia dotychczasowemu funkcjonariuszowi wybór, czy będzie on dochodził swych praw przed sądem powszechnym czy na drodze postępowania sądowoadministracyjnego. Jeżeli bowiem odmówi przyjęcia propozycji zatrudnienia w określonym przez prawo terminie, to będzie mu przysługiwało prawo wniesienia skargi do sądu administracyjnego (art. 170 ust. 3 p.w. KAS). Jeżeli zaś w wyniku przyjęcia złożonej mu propozycji zatrudnienia dojdzie 
do przekształcenia dotychczasowego stosunku służby w służbie przygotowawczej albo stałej w stosunek pracy, to będzie on mógł dochodzić swych praw przed sądem powszechnym.

W późniejszych orzeczeniach Naczelny Sąd Administracyjny uznaje, że propozycja zatrudnienia złożona funkcjonariuszowi mieści się w sferze władztwa służbowego (pracowniczego), stanowi jedynie etap realizacji ustawowego stanu faktycznego, którego dopełnieniem jest oświadczenie funkcjonariusza (pracownika) o przyjęciu propozycji albo o odmowie jej przyjęcia, albo też niezłożenie oświadczenia. Organ - przedkładając propozycję - występuje w charakterze pracodawcy, a nie jako organ administracji publicznej (wyrok Naczelnego Sądu Administracyjnego z dnia 24 kwietnia 2020 roku, I OSK 1000/19, LEX nr 3018174, który uchylił wyrok Wojewódzkiego Sądu Administracyjnego w Krakowie z dnia 14 listopada 2017 roku, III SA/Kr 890/17, LEX nr 2402045). W orzecznictwie tego sądu podkreśla się również, że organ nie miał obowiązku przedstawienia dotychczasowemu funkcjonariuszowi propozycji służby, a w konsekwencji brak jest podstaw do zobowiązywania organu do złożenia takiej propozycji (wyrok Naczelnego Sądu Administracyjnego z dnia 29 kwietnia 2020 roku, I OSK 3172/19, LEX nr 2986188).

W świetle stanowiska Naczelnego Sądu Administracyjnego zaprezentowanego w przedstawionej uchwale składu siedmiu sędziów „ucywilnieni” funkcjonariusze składali odwołania do sądów pracy, których orzeczenia i ich uzasadnienia również są zróżnicowane.

Wyrokiem z dnia 10 marca 2020 roku Sąd Rejonowy w Legnicy przywrócił powodów - „ucywilnionych” funkcjonariuszy Służby Celnej - na poprzednie warunki służby i płacy (IV P 105/19, baza orzeczeń Sądu Rejonowego w Legnicy), a apelacja od tego wyroku została oddalona przez Sąd Okręgowy w Legnicy wyrokiem z dnia 14 października 2020 roku (V Pa 28/20, baza orzeczeń Sądu Okręgowego w Legnicy). Takie samo rozstrzygnięcie wydał Sąd Rejonowy w Szczecinie-Centrum w wyroku z dnia 4 sierpnia 2020 roku (IX P 352/19, POSP). Odmienne stanowisko zaprezentował natomiast Sąd Rejonowy w Rzeszowie, oddalając powództwo o przywrócenie do służby (wyrok Sądu Rejonowego w Rzeszowie z dnia 9 listopada 2020 roku, IV P 237/19). Ponadto sądy rejonowe wydawały wyroki zasądzające odprawy dla „ucywilnionych” funkcjonariuszy oraz zobowiązujące do wydania świadectwa służby za wcześniejszy okres Służby Celnej (wyrok Sądu Rejonowego w Szczecinie-Centrum z dnia 16 października 2020 roku, IX P28/20, POSP).

Sąd Rejonowy w Legnicy we wskazanym wyroku (wyrok prawomocny) stanął przede wszystkim na stanowisku, że jest on właściwy do merytorycznego rozpoznania spraw o przywrócenie do służby na podstawie art. 45 i 177 Konstytucji $\mathrm{RP}^{6}$ uzupełnionych o przepisy dotyczące właściwości miejscowej i rzeczowej, mimo że sprawy te nie są sprawami z zakresu

6 Artykuł 45 Konstytucji RP: „Każdy ma prawo do sprawiedliwego i jawnego rozpatrzenia sprawy bez nieuzasadnionej zwłoki przez właściwy, niezależny, bezstronny i niezawisły sąd”. Artykuł 177 Konstytucji RP: „Sądy powszechne sprawują wymiar sprawiedliwości we wszystkich sprawach z wyjątkiem spraw ustawowo zastrzeżonych dla właściwości innych sądów". 
prawa pracy w rozumieniu art. $476 \$ 1$ ustawy z dnia 17 listopada 1964 roku - Kodeks postępowania cywilnego (Dz.U. 2021, poz. 1805 tekst jedn. ze zm.). Jednakże w wyniku stanowiska sądów administracyjnych „ucywilnieni” funkcjonariusze zostali w istocie pozbawieni możliwości dochodzenia swoich roszczeń. Sytuacja, jak wywodził Sąd Rejonowy w Legnicy, w której powodowie nie mogą uzyskać ochrony prawnej przed żadnym z sądów, to jest ani administracyjnym, ani powszechnym, jest nie do przyjęcia w demokratycznym państwie prawnym. Jest ona niedopuszczalna $z$ uwagi na istniejące domniemania kognicji sądu powszechnego, a to oznacza, że sąd powszechny powinien udzielić ochrony prawnej zabiegającej o nią osobie, gdy sprawa będąca przedmiotem postępowania ma cechy sprawy w rozumieniu art. 45 ust. 1 Konstytucji RP, choćby nie była sprawą cywilną. Sąd Rejonowy w Legnicy w swoim wywodzie powołał się na stanowisko prezentowane w tym zakresie przez Sąd Najwyższy (uchwała Sądu Najwyższego z dnia 8 stycznia 1992 roku, III CZP 138/91, OSNCP 1992, nr 7-8, poz. 128; postanowienie Sądu Najwyższego z dnia 22 sierpnia 2000 roku, IV CKN 1188/00, OSNC 2001, nr 1, poz. 20; uchwała składu siedmiu sędziów Sądu Najwyższego z dnia 12 marca 2003 roku, III CZP 85/02, OSNC 2003, nr 10, poz. 129) oraz Trybunał Konstytucyjny (wyrok Trybunału Konstytucyjnego z dnia 10 lipca 2000 roku, SK 12/99, OTK 2000, nr 5, poz. 143), wskazując też art. 6 ust. 1 Konwencji o ochronie praw człowieka i podstawowych wolności (Dz.U. 1993, nr 61, poz. 284) ${ }^{7}$. Sąd wskazał na fakt zamknięcia powodom dochodzenia swoich racji na drodze sądowoadministracyjnej oraz wydanie uchwały składu siedmiu sędziów Naczelnego Sądu Administracyjnego w sprawie I OPS 1/19, ONSAi WSA 2019, nr 5, poz. 71, w której wskazano, że osobom znajdującym się w takiej sytuacji przysługuje możliwość dochodzenia swoich roszczeń na drodze cywilnoprawnej.

Sąd Rejonowy w Legnicy, prowadząc dalsze wywody, zwrócił uwagę na bardzo istotną kwestię, a mianowicie, że zwolniony ze służby funkcjonariusz w wyniku wydanej decyzji administracyjnej może szukać ochrony na drodze sądownictwa administracyjnego. W odmiennej sytuacji jest natomiast funkcjonariusz, który był zmuszony obawą przed utratą pracy do wyrażenia zgody na przekształcenie. Brak jest jakiegokolwiek przepisu w ustawie wprowadzającej bądź w ustawie o KAS, który wskazywałby na drogę cywilnoprawną w takim przypadku. Sąd zaprezentował wniosek, że ustawodawca nie wprowadził mechanizmu kontrolnego, aby uniknąć możliwości sprawdzenia podejmowanych de facto decyzji wobec funkcjonariuszy tracących swój status. Dowodem na tę tezę jest chociażby sytuacja prawna „ucywilnionych” funkcjonariuszy, którzy od kilku lat bezskutecznie usiłowali znaleźć prawną możliwość kontroli przyczyn i mechanizmów pozbawiających ich statusu funkcjonariusza, to jest odnaleźć właściwą drogę sądową. Sądownictwo administracyjne odmówiło zajęcia się tą sprawą, wskazując na brak wydanej decyzji administracyjnej, a więc brak aktu

7 „Każdy ma prawo do sprawiedliwego i publicznego rozpatrzenia jego sprawy w rozsądnym terminie przez niezawisły i bezstronny sąd ustanowiony ustawą przy rozstrzyganiu o jego prawach i obowiązkach o charakterze cywilnym albo o zasadności każdego oskarżenia w wytoczonej przeciwko niemu sprawie karnej". 
administracyjnego, który mógłby zostać skontrolowany; sądownictwo powszechne uznało, że sprawa ta nie jest sprawą z zakresu prawa pracy, lecz wynika ze stosunku prawnego o charakterze administracyjnoprawnym. Osoby te znalazły się w sytuacji, w której żaden organ nie uznawał się właściwy do rozpoznania sprawy. Oznacza to, że ustawodawca nie wprowadził mechanizmu kontroli zasad przekształcenia stosunku służbowego w stosunek pracy. W ocenie Sądu Rejonowego w Legnicy postawienie funkcjonariuszy przed wyborem - albo podpisanie oświadczenia o przyjęciu złożonych im propozycji określających dla każdego $\mathrm{z}$ nich warunki zatrudnienia $\mathrm{w}$ ramach korpusu służby cywilnej w izbie administracji skarbowej, albo utrata pracy wiążąca się z ustaniem służby - jest de facto postawieniem ich w sytuacji przymusowej i realnie wyklucza element dobrowolności w podejmowaniu takiej decyzji.

W dalszej części wywodów Sąd Rejonowy w Legnicy, nie negując zasadności reformy administracji celno-skarbowej, wskazał, że przy reformie obejmującej funkcjonariuszy państwowych, mając na względzie trwałość ich stosunku służbowego i wynikające z niego gwarancje pewności zatrudnienia, konieczne jest wprowadzenie jasnych, konkretnych i mierzalnych kryteriów naboru bądź też weryfikacji, które umożliwią transparentny proces oceny każdego funkcjonariusza, uwzględniając zasady równego traktowania (wyrok Trybunału Konstytucyjnego z dnia 20 kwietnia 2004 roku, K 45/02, Dz.U. 2004, nr 109, poz. 1159). W konsekwencji Sąd Rejonowy w Legnicy uznał, że normy prawne umożliwiające wygaśnięcie stosunków służbowych funkcjonariuszy Służby Celnej, zawierające nieostre kryteria, pozostają w kolizji z treścią art. 60 w zw. z art. 7 i 2 Konstytucji RP. Zwolnienie ze służby wykwalifikowanych funkcjonariuszy celnych oraz „ucywilnienie” znacznej części dotychczasowej kadry pozostaje także $\mathrm{w}$ funkcjonalnym związku $\mathrm{z}$ wyrażonym w art. 84 Konstytucji RP obowiązkiem ponoszenia ciężarów i świadczeń publicznych.

Sąd Rejonowy w Szczecinie-Centrum w powołanym wcześniej wyroku, którego treść jest tożsama z wyrokiem Sądu Rejonowego w Legnicy, przyjął natomiast nieco odmienną argumentację. Przywracając powódkę do służby na podstawie art. 67 k.p. w zw. z art. 56 k.p., uznał wygaśnięcie stosunku służby „,ucywilnionego" funkcjonariusza za niezgodne z prawem i sprzeczne z zasadami współżycia społecznego. Wywodził, że stosunek służbowy nie istnieje dalej, gdy funkcjonariusz przyjmuje propozycję pracowniczego zatrudnienia. W aspekcie dalszego zatrudnienia funkcjonariusz może zatem decydować tylko o nawiązaniu stosunku pracy, na co wskazał wprost Sąd Najwyższy w uchwale z dnia 19 lutego 2020 roku (III PZP 7/19, OSNP 2020, nr 7, poz. 63), stosując wykładnię systemową i celowościową. Jednocześnie, co podkreślił Sąd Najwyższy, a który to pogląd Sąd Rejonowy w Szczecinie-Centrum przyjął za własny, prawodawca nie może zadekretować mocą ustawy zmiany stosunku służbowego w stosunek pracy. Sprzeciwia się temu zasada swobody nawiązania stosunku pracy oparta na wolnej woli zatrudnianego (art. 11 k.p.). Oznacza to, że również administracja celno-skarbowa nie może dowolnie „przekształcić” stosunku służbowego funkcjonariusza, gdyż zmiana stosunku służby to materia ściśle określona w pragmatyce służbowej (ustawie). Analiza ta nie jest też sprzeczna z uchwałą Naczelnego Sądu Administracyjnego z 1 lipca 2019 roku. Aby stwierdzić ustanie stosunku służbowego, nie jest konieczne wydanie 
decyzji o zwolnieniu ze służby, gdy dochodzi do tak ujętego przekształcenia stosunku służby w stosunek pracy („ucywilnienia”). Nie jest to jednak „przekształcenie”, w którym nowy stosunek pracy zastępuje poprzedni, lecz sytuacja, w której poprzedni stosunek służby ulega zakończeniu i strony zawierają nowy (odrębny) stosunek prawny (stosunek pracy). Wybór zatrudnienia pracowniczego nie oznacza zatem, że stosunek służbowy się nie zakończył. Ustanie w takiej sytuacji stosunku służbowego, wynikające w istocie z uzgodnienia, że funkcjonariusz będzie zatrudniony jako pracownik, uzasadnia stwierdzenie, że w istocie dochodzi do zwolnienia z dotychczasowej służby. Stosunek pracy powstaje z woli stron i jest to warunek zakończenia (ustania) stosunku służbowego. Zawarcie umowy o pracę stanowi też kauzę zakończenia stosunku służbowego. Nawet więc w przypadku przyjęcia propozycji zatrudnienia, jak również w przypadku odrzucenia tejże propozycji (o czym jest mowa w przepisie ust. 1 pkt 2 ustawy wprowadzającej) stosunek służby wygasa. Przyjęcie wniosku, iż stosunek służby wygasł, dawał podstawy do badania prawidłowości tego wygaśnięcia na podstawie regulacji Kodeksu pracy. W ocenie sądu rejonowego nie przeczy temu sam fakt przyjęcia oferty nawiązania stosunku pracy, uwarunkowany trudną sytuacją osobistą i koniecznością zapewnienia ciągłości środków utrzymania rodziny. Każdorazowo bowiem sąd powszechny - badając zgodność z prawem wygaśnięcia stosunku prawnego - musi mieć możliwość weryfikacji jego zasadności, w szczególności gdy chodzi o funkcjonariusza, którego dotychczasowy stosunek służby podlegał większej ochronie niż w przypadku „zwykłego” pracownika. „Ucywilniony” funkcjonariusz nie może być pozbawiony minimalnych standardów ochrony stosunku służby wynikających z ogólnych reguł prawa pracy. Pozwany (izba administracji skarbowej) nie może nadużywać prawa w ujęciu klauzuli z art. 8 k.p. w zw. z art. 5 k.p. i w sposób arbitralny dokonywać zwolnień ze służby w ramach wygaśnięcia stosunku zatrudnienia, korzystając z reformy administracji państwowej, z pominięciem konstytucyjnego prawa do pracy i służby publicznej. Klauzule generalne zasad współżycia społecznego i społeczno-gospodarczego przeznaczenia prawa stosuje się w sytuacji, gdy podmiot uprawniony korzysta z przysługującego mu prawa podmiotowego w sposób niemożliwy do zaakceptowania, naruszający powszechnie podzielane poczucie sprawiedliwości i przyzwoitości. Sąd zwrócił też uwagę, że na mocy art. 24 i art. 32 ust. 1 Konstytucji RP praca znajduje się pod ochroną Rzeczypospolitej Polskiej, wszyscy są wobec prawa równi, wszyscy mają prawo do równego traktowania przez władze publiczne. Zasada równości polega na tym, że wszystkie podmioty (adresaci norm prawnych) charakteryzujące się daną cechą istotną (relewantną) w stopniu równym mają być traktowane równo. Normy konstytucyjne nie zezwalają zatem w demokratycznym państwie prawnym, by szczególna pozycja państwa wyrażająca się w tworzeniu przepisów prawa dla administracji publicznej była wykorzystana dla arbitralnego zwolnienia szeroko rozumianej grupy pracowników państwowych z pominięciem ograniczeń w rozwiązaniu stosunków zatrudnienia obowiązujących u pracodawców spoza sektora publicznego. W przeciwnym razie władztwo publiczne staje się narzędziem mającym na celu szczególne i uprzywilejowane traktowanie państwa jako działającego arbitralnie pracodawcy, niestosującego generalnej klauzuli zasadności 
wypowiadania stosunku pracy w ramach zatrudnienia na czas nieokreślony. Trudno przyjąć na tle regulacji Konstytucji RP, zakazów dyskryminacji przewidzianych choćby na poziomie Kodeksu pracy oraz zasad współżycia społecznego, że funkcjonariusz administracji publicznej nie ma żadnej ochrony swojego stosunku zatrudnienia przed jego rozwiązaniem, nie ma żadnego bezpieczeństwa prawnego w tym zakresie. Taka interpretacja w pełni uwzględnia zasady wynikające z prawa unijnego.

\section{Zakończenie}

Przedstawione rozwiązania prawne wprowadzone w związku z reformą administracji celno-skarbowej oraz kształtowane na ich tle orzecznictwo sądów administracyjnych i sądów powszechnych jednoznacznie wskazują na niedoskonałości legislacyjne (a może celowe i przemyślane działania), a także trudności w ich interpretacji przez sądy. Trudności te dotyczą przepisów przewidujących zarówno wygaśnięcie stosunku służbowego z mocy ustawy, jak i „ucywilnienie” funkcjonariuszy celnych. Analiza tych rozwiązań, które dotyczą funkcjonariuszy i pracowników wcześniejszych struktur administracji celno-skarbowej, a także tożsamych przyjętych wcześniej na gruncie reformy administracji rolnej, uzasadnia postawienie tezy, że jest to środek do wymiany kadry (Ura 2018, s. 274 i n.). Ustawodawca sięga do tych rozwiązań nie tylko w „szczególnie uzasadnionych okolicznościach związanych z reformą ustrojową" - jak wskazywał Trybunał Konstytucyjny - lecz także przy okazji każdej reformy administracji publicznej i jej poszczególnych działów (była służba cywilna, agencje rolne, a teraz administracja celno-skarbowa).

Dodatkowo, co należy podkreślić, po raz pierwszy przy reformach administracji zastosowano instytucję ,ucywilniania” funkcjonariuszy, czyli przekształcenia stosunku służbowego w stosunek pracy przy wymogu przyjęcia propozycji nowej pracy. Jednocześnie, co zauważył jeden z sądów rejonowych w przywołanym wcześniej wyroku, w przypadku funkcjonariuszy tracących swój status, a pragnących mimo wszystko kontynuować zatrudnienie u dotychczasowego pracodawcy, ustawodawca nie zapewnił możliwości dochodzenia $\mathrm{z}$ tego tytułu roszczeń do jakiegokolwiek organu sądowego (ani sądu administracyjnego, ani sądu pracy). Wziąć trzeba też pod uwagę, co również podkreślano w orzeczeniach, że przekształcenie stosunku zatrudnienia z mianowania (stosunku służbowego) w stosunek pracy na podstawie umowy o pracę powoduje pogorszenie sytuacji prawnej funkcjonariusza.

Dokonując selekcji funkcjonariuszy celnych, nie zastosowano żadnych kryteriów ocennych. Powstały sytuacje, że funkcjonariusz, któremu brakowało do wysługi emerytalnej kilku miesięcy, nie dostał propozycji dalszej służby bądź został „ucywilniony”. I jedna, i druga sytuacja pozbawia go emerytury funkcjonariusza. Czy w takiej sytuacji doprowadzenie do wygaśnięcia stosunków służbowych funkcjonariuszy nie tylko w przypadku niezaproponowania dalszej służby, ale także wskutek „ucywilnienia” dotychczasowych stosunków służbowych bez stosowania jasnych i czytelnych kryteriów nie stanowiło 
nadużycia prawa przez dyrektorów izb administracji celnej? Czy są to rzeczywiście wyjątkowe sytuacje, związane z koniecznością realizowania innych ważnych wartości konstytucyjnych, na które zwracał uwagę Trybunał Konstytucyjny?

Należy tu zauważyć, że żaden z sądów nie dokonał literalnej wykładni przepisów, na co wskazywali odwołujący się funkcjonariusze. A już w uzasadnieniu do projektu ustawy wprowadzającej wskazano, że:

\footnotetext{
W przypadku przyjęcia propozycji zatrudnienia albo pełnienia służby art. 170 statuuje zasady dotyczące kontynuacji zatrudnienia/służby. Przyjmuje się, że stosunki pracy oraz stosunki służby przekształcają się odpowiednio w stosunki pracy albo w stosunki służby w Służbie Celno-Skarbowej (uzasadnienie poselskiego projektu ustawy - Przepisy wprowadzające ustawę o Krajowej Administracji Skarbowej (2016), druk sejmowy nr 827, Sejm VIII kadencji).
}

Analiza tego sformułowania prowadzi do wniosku, że, zgodnie z wolą prawodawcy pracownicy administracji celno-skarbowej powinni otrzymać propozycję zatrudnienia, a funkcjonariusze - propozycję pełnienia służby. Praktyka stosowania prawa przez dyrektorów izb administracji skarbowej poszła jednak w zupełnie innym kierunku.

\section{Bibliografia}

Biuletyn Informacji Publicznej RPO (2020) Jakie są koszty odszkodowań za wygaśnięcie stosunków pracy przy reformie administracji rolnej? RPO pyta Ministra Rolnictwa, https://www.rpo. gov.pl/pl/content/rpo-pyta-ministra-rolnictw-o-koszty-odszkodowan-dla-zwolnionych-z-administracji-rolnej (dostęp: 31 marca 2021).

NIK (2020) NIK o zmianach $w$ organizacji i funkcjonowaniu administracji rolnej, https://www. nik.gov.pl/aktualnosci/zmiany-w-organizacji-i-funkcjonowaniu-administracji-rolnej.html (dostęp: 31 marca 2021).

Nowak I. (2020) National Revenue Administration - Current Organisational and Financial Problems, „Prawo Budżetowe Państwa i Samorządu”, nr 2.

Płażek S. (2019) Wygaśnięcie stosunków pracy z mocy prawa w administracji publicznej,„Praca i Zabezpieczenie Społeczne", nr 2.

Świątkowski A. (2018) Pozakodeksowe przypadki wygaśnięcia stosunku pracy, „Palestra”, nr 3.

Ura E. (1995) Pozycja prawna pracowników terenowej administracji rządowej i samorządu terytorialnego, Lublin.

Ura E. (2018) Wprowadzanie reform $w$ strukturach administracji publicznej jako środek do wymiany kadr tej administracji [w:] A. Jabłoński, T. Kuczyński (red.), Prawo pracy i prawo ubezpieczeń społecznych. Teraźniejszość i przyszłość. Księga jubileuszowa Profesora Zdzisława Kubota, Warszawa 2018.

Uzasadnienie poselskiego projektu ustawy o Krajowej Administracji Skarbowej (2016), druk sejmowy nr 826, Sejm VIII kadencji.

Uzasadnienie poselskiego projektu ustawy - Przepisy wprowadzające ustawę o Krajowej Administracji Skarbowej (2016), druk sejmowy nr 827, Sejm VIII kadencji. 


\section{Orzecznictwo}

Postanowienie Naczelnego Sądu Administracyjnego z dnia 17 maja 2018 roku, I OSK 1556/18, LEX nr 2593456.

Postanowienie Naczelnego Sądu Administracyjnego z dnia 22 sierpnia 2019 roku, I OSK 705/18, LEX nr 2713904.

Postanowienie Sądu Najwyższego z dnia 22 sierpnia 2000 roku, IV CKN 1188/00, OSNC 2001, nr 1, poz. 20.

Postanowienie Wojewódzkiego Sądu Administracyjnego w Poznaniu z dnia 4 października 2017 roku, II SAB/Po 145/17, LEX nr 2423141.

Postanowienie Wojewódzkiego Sądu Administracyjnego w Warszawie z dnia 25 października 2017 roku, II SAB/Wa 511/17, LEX nr 2469409.

Postanowienie Wojewódzkiego Sądu Administracyjnego we Wrocławiu z dnia 23 listopada 2017 roku, IV SA/Wr 665/17, LEX nr 2424198.

Uchwała Sądu Najwyższego z dnia 8 stycznia 1992 roku, III CZP 138/91, OSNCP 1992, nr 7-8, poz. 128.

Uchwała Sądu Najwyższego z dnia 19 lutego 2020 roku, III PZP 7/19, OSNP 2020, nr 7, poz. 63. Uchwała składu siedmiu sędziów Naczelnego Sądu Administracyjnego z dnia 1 lipca 2019 roku, I OPS 1/19, ONSA i WSA 2019, nr 5, poz. 71.

Uchwała składu siedmiu sędziów Sądu Najwyższego z dnia 12 marca 2003 roku, III CZP 85/02, OSNC 2003, nr 10, poz. 129.

Wyrok Naczelnego Sądu Administracyjnego z dnia 7 marca 2017 roku, I OSK 316/2016, CBOSA.

Wyrok Naczelnego Sądu Administracyjnego z dnia 10 kwietnia 2018 roku, I OSK 2768/17, LEX nr 2590998.

Wyrok Naczelnego Sądu Administracyjnego z dnia 5 listopada 2018 roku, I OSK 1044/18, LEX nr 2629079.

Wyrok Naczelnego Sądu Administracyjnego z dnia 11 marca 2020 roku, I OSK 2767/19, LEX nr 3009676.

Wyrok Naczelnego Sądu Administracyjnego z dnia 24 kwietnia 2020 roku, I OSK 1000/19, LEX nr 3018174.

Wyrok Naczelnego Sądu Administracyjnego z dnia 29 kwietnia 2020 roku, I OSK 3172/19, LEX nr 2986188.

Wyrok Naczelnego Sądu Administracyjnego z dnia 15 stycznia 2021 roku, III OSK 1407/21, LEX nr 3117611.

Wyrok Sądu Najwyższego z dnia 24 maja 2001 roku, I PKN 399/00, OSNP 2003, nr 6, poz. 143. Wyrok Sądu Najwyższego z dnia 16 czerwca 2009 roku, I PK 24/09, LEX nr 515695.

Wyrok Sądu Najwyższego z dnia 26 września 2019 roku, III PK 126/18, OSNP 2020, nr 8, poz. 79. Wyrok Sądu Najwyższego z dnia 22 stycznia 2020 roku, I PK 209/18, LEX 2772555.

Wyrok Sądu Najwyższego z dnia 12 sierpnia 2020 roku, II PK 4/19, LEX nr 3071522.

Wyrok Sądu Okręgowego w Legnicy z dnia 14 października 2020 roku, V Pa 28/20, baza orzeczeń Sądu Okręgowego w Legnicy. 
Wyrok Sądu Rejonowego w Legnicy z dnia 10 marca 2020 roku, IV P 105/19, baza orzeczeń Sądu Rejonowego w Legnicy.

Wyrok Sądu Rejonowego w Rzeszowie z dnia 9 listopada 2020 roku, IV P 237/19.

Wyrok Sądu Rejonowego w Szczecinie-Centrum z dnia 4 sierpnia 2020 roku, IX P 352/19, POSP. Wyrok Sądu Rejonowego w Szczecinie-Centrum z dnia 16 października 2020 roku, IX P28/20, POSP.

Wyrok Trybunału Konstytucyjnego z dnia 23 września 1997 roku, K 25/96, OTK ZU 1997, nr 3-4, poz. 36.

Wyrok Trybunału Konstytucyjnego z dnia 14 grudnia 1999 roku, SK 14/98, OTK ZU 1999, nr 7, poz. 163.

Wyrok Trybunału Konstytucyjnego z dnia 13 marca 2000 roku, K 1/99, OTK 2000, nr 2, poz. 59. Wyrok Trybunału Konstytucyjnego z dnia 10 lipca 2000 roku, SK 12/99, OTK 2000, nr 5, poz. 143. Wyrok Trybunału Konstytucyjnego z dnia 27 stycznia 2003 roku, SK 27/02, OTK ZU 2003, nr 1A, poz. 2.

Wyrok Trybunału Konstytucyjnego z dnia 20 kwietnia 2004 roku, K 45/02, Dz.U. 2004, nr 109, poz. 1159.

Wyrok Trybunału Konstytucyjnego z dnia 19 października 2004 roku, K 1/04, OTK-A 2004, nr 9, poz. 93.

Wyrok Trybunału Konstytucyjnego z dnia 13 lutego 2007 roku, K 46/05, OTK-A 2007, nr 2, poz. 10.

Wyrok Trybunału Konstytucyjnego z dnia 12 lipca 2011 roku, K 26/09, OTK-A 2011, nr 6, poz. 54.

Wyrok Trybunału Konstytucyjnego z dnia 23 stycznia 2014 roku, K 51/12, OTK 2014, nr 1, poz. 4.

Wyrok Trybunału Konstytucyjnego z dnia 24 października 2017 roku, K 1/17, OTK-A 2017, poz. 79.

Wyrok Wojewódzkiego Sądu Administracyjnego w Bydgoszczy z dnia 28 października 2015 roku, II SA/Bd 878/15, LEX nr 1948741.

Wyrok Wojewódzkiego Sądu Administracyjnego w Kielcach z dnia 21 listopada 2017 roku, II SAB/Ke 63/17, LEX nr 2422880.

Wyrok Wojewódzkiego Sądu Administracyjnego w Krakowie z dnia 14 listopada 2017 roku, III SA/Kr 890/17, LEX nr 2402045.

Wyrok Wojewódzkiego Sądu Administracyjnego w Olsztynie z dnia 19 października 2017 roku, II SA/Ol 672/17, LEX nr 2381494.

Wyrok Wojewódzkiego Sądu Administracyjnego w Szczecinie z dnia 4 października 2017 roku, II SA/Sz 897/17, LEX nr 2377612.

Wyrok Wojewódzkiego Sądu Administracyjnego w Warszawie z dnia 24 października 2013 roku, II SA/Wa 1188/13, LEX nr 1637335.

Wyrok Wojewódzkiego Sądu Administracyjnego w Warszawie z dnia 23 kwietnia 2020 roku, II SA/Wa 2652/19, LEX nr 3072213. 


\section{Akty prawa krajowego}

Konstytucja Rzeczypospolitej Polskiej z dnia 2 kwietnia 1997 roku, Dz.U. 1997, nr 78, poz. 483 z dnia 16 lipca 1997 roku.

Ustawa z dnia 14 czerwca 1960 roku - Kodeks postępowania administracyjnego, Dz.U. 2021, poz. 735 tekst jedn.

Ustawa z dnia 17 listopada 1964 roku - Kodeks postępowania cywilnego, Dz.U. 2021, poz. 1805 tekst jedn. ze zm.

Ustawa z dnia 26 czerwca 1974 roku - Kodeks pracy, Dz.U. 2020, poz. 1320 tekst jedn. ze zm.

Ustawa z dnia 22 marca 1990 roku o pracownikach samorządowych, Dz.U. 1990, nr 21, poz. 124.

Ustawa z dnia 28 września 1991 roku o kontroli skarbowej, Dz.U.2016, poz. 720 tekst jedn. ze zm.

Ustawa z dnia 21 czerwca 1996 roku o urzędzie Ministra Finansów oraz o urzędach i izbach skarbowych, Dz.U. 2015, poz. 578 tekst jedn. ze zm.

Ustawa z dnia 13 października 1998 roku - Przepisy wprowadzające ustawy reformujące administrację publiczną, Dz.U. 1988, nr 133, poz. 872.

Ustawa $\mathrm{z}$ dnia 30 sierpnia 2002 roku - Prawo o postępowaniu przed sądami administracyjnymi, Dz.U. 2019, poz. 2325 tekst jedn.

Ustawa z dnia 27 sierpnia 2009 roku o Służbie Celnej, Dz.U. 2016, poz. 1799 tekst jedn. ze zm. Ustawa z dnia 10 lipca 2015 roku o administracji podatkowej, Dz.U. 2015, poz. 1269 ze zm. Ustawa z dnia 16 listopada 2016 roku o Krajowej Administracji Skarbowej, Dz.U. 2021, poz. 422 tekst jedn. ze zm.

Ustawa z dnia 16 listopada 2016 roku - Przepisy wprowadzające ustawę o Krajowej Administracji Skarbowej, Dz.U. 2016, poz. 1948.

Ustawa z dnia 10 lutego 2017 roku o Krajowym Ośrodku Wsparcia Rolnictwa, Dz.U. 2020, poz. 481 tekst jedn.

Ustawa z dnia 10 lutego 2017 roku - Przepisy wprowadzające ustawę o Krajowym Ośrodku Wsparcia Rolnictwa, Dz.U. 2017, poz. 624.

\section{Akty prawa międzynarodowego}

Konwencja o ochronie praw człowieka i podstawowych wolności sporządzona w Rzymie dnia 4 listopada 1950 roku, zmieniona następnie Protokołami nr 3, 5 i 8 oraz uzupełniona Protokołem nr 2, Dz.U. 1993, nr 61, poz. 284. 